\title{
RESEARCH ON BURNOUT LEVEL OF JUVENILE \\ TRAMPOLINISTS AND RELEVANT AFFECTING FACTORS
}

\author{
PESQUISA SOBRE O NIVEL DE BURNOUTDE TRAMPOLINISTAS JUVENIS E FATORES AFETIVOS \\ RELEVANTES
}

Original Article

ARTIGO ORIGINAL

Artículo Original

\author{
INVESTIGACIÓN SOBRE EL NIVEL DE BURNOUTDE LOS TRAMPOLINISTAS JUVENILES Y LOS FACTORES \\ AFECTIVOS RELEVANTES
}

\author{
Benyu Feng 1 (D) \\ (Physical Education Professional) \\ Yu Yuan' (1D) \\ (Physical Education Professional)
}

1. School of physical education, Shanxi University, Taiyuan, China.

\section{Correspondence:}

Benyu Feng

School of physical education,

Shanxi University, Taiyuan, 030006,

China.fbygw@sxu.edu.cn

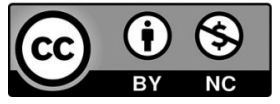

\begin{abstract}
Introduction: The paper investigates burnout causes and relevant affecting factors of juvenile trampolinists. Objective: With 93 participants aged U10-16 of 2019 National Juvenile Trampoline Championship as investigation objects, to improve the current situation of juvenile burnout, exploring the methodology to alleviate and eliminate it, enhancing the sense of achievement in training and competition and providing a theoretical basis for coaches to train and cultivate athletes. Methods: Questionnaire survey, semi-structured interview, mathematical statistics. Results: The burnout level of the trampolinists is below the moderate level, and the overall burnout level of athletes is not high; the sense of achievement decrease $>$ negative evaluation of sports>emotional/physical exhaustion; the correlation between the overall level of burnout of athletes and different genders, training age, education stage and athlete level is not significant; in terms of burnout, there are very significant positive correlations $(\mathrm{P}<0.01)$ between overload factor, personal factor, and situational factor, and emotional/physical exhaustion, sense of achievement decrease and negative evaluation of sports respectively. Conclusions: Strengthen the communication with trampolinists, improve their self-regulation ability in various ways, master the methods to alleviate burnout, and increase social support for them. Level of evidence Il; Therapeutic studies - investigation of treatment results.
\end{abstract}

Keywords: Adolescent; Trampolinists; Burnout, Psychological.

\section{RESUMO}

Introdução: $O$ artigo investiga as causas do burnout e os fatores que afetam os jovens trampolinistas. Objetivo: Ter como objeto de pesquisa 93 participantes de U10-16 do Campeonato Nacional Juvenil de Trampolim 2019, para melhorar a situação atual do burnout juvenil, explorando a metodologia para amenizá-lo e eliminá-lo, potencializando a sensação de realização em treinamentos e competições e proporcionando uma base para os treinadores trabalharem com os atletas. Métodos: Questionário de levantamento, entrevista semiestruturada, estatística matemática. Resultados: O nível de burnout dos trampolinistas está abaixo do nível moderado e o nivel geral de burnout dos atletas não é alto; diminuição da sensação de realização> avaliação negativa de esportes > burnout emocional/físico; a correlação entre o nível geral de burnout dos atletas e os diferentes gêneros, a idade de treinamento, o estágio educacional e o nível do atleta não é significativa; Em termos de burnout, existem correlações positivas altamente significativas $(P<0,01)$ entre 0 fator de sobrecarga, o fator pessoal e o fator situacional, e burnout emocional/físico, a diminuição do senso de realização e a avaliação negativa dos esportes, respectivamente. Conclusões: Fortalecer a comunicação com os trampolinistas, melhorar sua capacidade de autorregulação de várias maneiras, dominar os métodos para aliviar o burnout e aumentar o apoio social para eles. Nível de evidência Il; Estudos terapêuticos: investigação dos resultados do tratamento.

Descritores: Adolescente; Trampolinistas; Esgotamento Psicológico.

\section{RESUMEN}

Introducción: El artículo investiga las causas del burnouty los factores que afectan a los trampolinistas juveniles. Objetivo: Con 93 participantes de edades U10-16 del Campeonato Nacional Juvenil de Trampolín 2019 como objetos de investigación, mejorar la situación actual del burnoutjuvenil, explorando la metodología para aliviarlo y eliminarlo, potenciando el sentido de logro en entrenamientos y competencias y brindando un base para que los entrenadores trabajen con los atletas. Métodos: Encuesta por cuestionario, entrevista semiestructurada, estadística matemática. Resultados: El nivel de burnout de los trampolinistas está por debajo del nivel moderado y el nivel de burnout general de los atletas no es alto; disminución del sentido de logro > evaluación negativa de los deportes > burnout emocional/ físico; l correlación entre el nivel general de burnout de los atletas y los diferentes géneros, la edad de entrenamiento, la etapa educativa y el nivel del atleta no es significativa; en términos de burnout, existen correlaciones positivas muy significativas $(P<0,01)$ entre el factor de sobrecarga, el factor personal y el factor situacional, yel burnout emocional 
Ifísico, la disminución del sentido de logro y la evaluación negativa de los deportes, respectivamente. Conclusiones: Fortalecer la comunicación con los trampolinistas, mejorar su capacidad de autorregulación de diversas formas, dominar los métodos para aliviar el burnout y aumentar el apoyo social a ellos. Nivel de evidencia Il; Estudios terapéuticos: investigación de los resultados del tratamiento.

Descriptores: Adolescente; Trampolinistas; Agotamiento Psicológico.

\section{INTRODUCTION}

Trampoline is a sort of skill-oriented difficulty-artistic event-group, and psychological stability has an important impact on the performance and competitive level of juvenile trampolinists. In training or competitions, athletes probably experience physical exhaustion, sense of achievement decrease, and negative evaluation of sports due to pressure, and such negative phenomena are named burnout. ${ }^{1,2}$ Trampoline is a sort of high-risk sport, which requires athletes to be highly concentrated on the process of completing their movements. If trampolinists have lack of good psychological quality or have distraction in the competition, sports injuries are likely to occur. Burnout is a sort of psychosocial syndrome and intense competitions will make trampolinists prone to burnout, resulting in insomnia, tiredness of training and other psychologically negative phenomena. Therefore, researches on athlete burnout have important practical value. ${ }^{3,4}$ Investigations can help find problems relevant to the training and competition in time, for the sake of early detection and early prevention.

\section{METHODS}

\section{Research object}

The Table 1 indicates that the average age of male athletes is $13.37 \pm 1.53$ and female 12.27 \pm 1.54 ; the average training age of male athletes is $5.89 \pm 2.76$ and female $5.22 \pm 2.14$.

Table 1. An overview of research objects' basic information.

\begin{tabular}{c|c|c|c|c|c|c|c|c|c|c|c}
\hline \multicolumn{2}{c|}{ Gender } & \multicolumn{2}{|c|}{ Education stage } & \multicolumn{4}{c|}{ Athlete Level } & \multicolumn{3}{c}{ Training Age } \\
\hline M & F & $\begin{array}{c}\text { Primary } \\
\text { School }\end{array}$ & $\begin{array}{c}\text { Junior } \\
\text { High } \\
\text { School }\end{array}$ & $\begin{array}{c}\text { Senior } \\
\text { High } \\
\text { School }\end{array}$ & None & $\begin{array}{c}\text { Second } \\
\text { Grade }\end{array}$ & $\begin{array}{c}\text { First } \\
\text { Grade }\end{array}$ & Master & $\begin{array}{c}1-3 \\
\text { years }\end{array}$ & $\begin{array}{c}4-6 \\
\text { years }\end{array}$ & $\begin{array}{l}\text { Over 6 } \\
\text { years }\end{array}$ \\
\hline 56 & 37 & 25 & 51 & 17 & 22 & 26 & 39 & 6 & 22 & 38 & 33 \\
\hline
\end{tabular}

\section{Research methods}

A total of 95 questionnaires were collected with a recovery rate of 97.94\%, among which 93 were valid and the validity rate was $97.90 \%$. Cronbach a

\section{Coefficient of the questionnaire is $\mathbf{0 . 8 3 6}$}

The questionnaire has designed questions relevant to burnout and semi-structured interviews were conducted with part of athletes, coaches and managers.

The relevant data in the questionnaire were input into and analyzed by SPSS23.0, including descriptive statistics, regression analysis and variance analysis.

\section{RESULTS AND RELEVANT ANALYSIS}

\section{Investigation on burnout of juvenile trampolinists}

The average score of burnout of juvenile trampolinists aged U10-16 is 2.18 , the burnout level of trampolinists is below the moderate level and not generally high. and therefore, these three indexes of juvenile trampolinists are "sense of achievement decrease" (2.44 score),"negative evaluation of sports"(2.42 score) and "emotional/physical exhaustion", whichis below the moderate level. With the comprehension of general burnout level of the trampolinists, sense of achievement decrease $>$ negative evaluation of sports > emotional/physical exhaustion.

Significance value between overall burnout score and genders is 0.251 , emotional/physical exhaustion > sense of achievement decrease $>$ negative evaluation of sports, which means emotional/physical exhaustion is lower.

Figure 1 indicates that the average value of burnout, emotional and physical exhaustion, sense of achievement decrease and negative evaluation of sports of female players are all higher than those of male players, which indicates that juvenile female trampolinists are more likely to develop burnout. Coaches should encourage female athletes, and often interact and play games with them, and provide emotional support for them to improve their self-consciousness. ${ }^{5,6}$ Coaches should promptly correct the evaluation way of female athletes, comfort female athletes who are faced with problems, and guide and change their behavior of negative evaluation of sports.

Significance value between overall score of juvenile trampolinists and their training age is 0.406 , emotional/physical exhaustion > negative evaluation of sports $>$ sense of achievement decrease . $^{7-9}$

The Figure 2 indicates that the average value of burnout of juvenile trampolinists with different training age varies greatly. Attention should be paid to the situation of emotional and physical exertion of the athletes, and appropriate adjustments should be made to the training content,
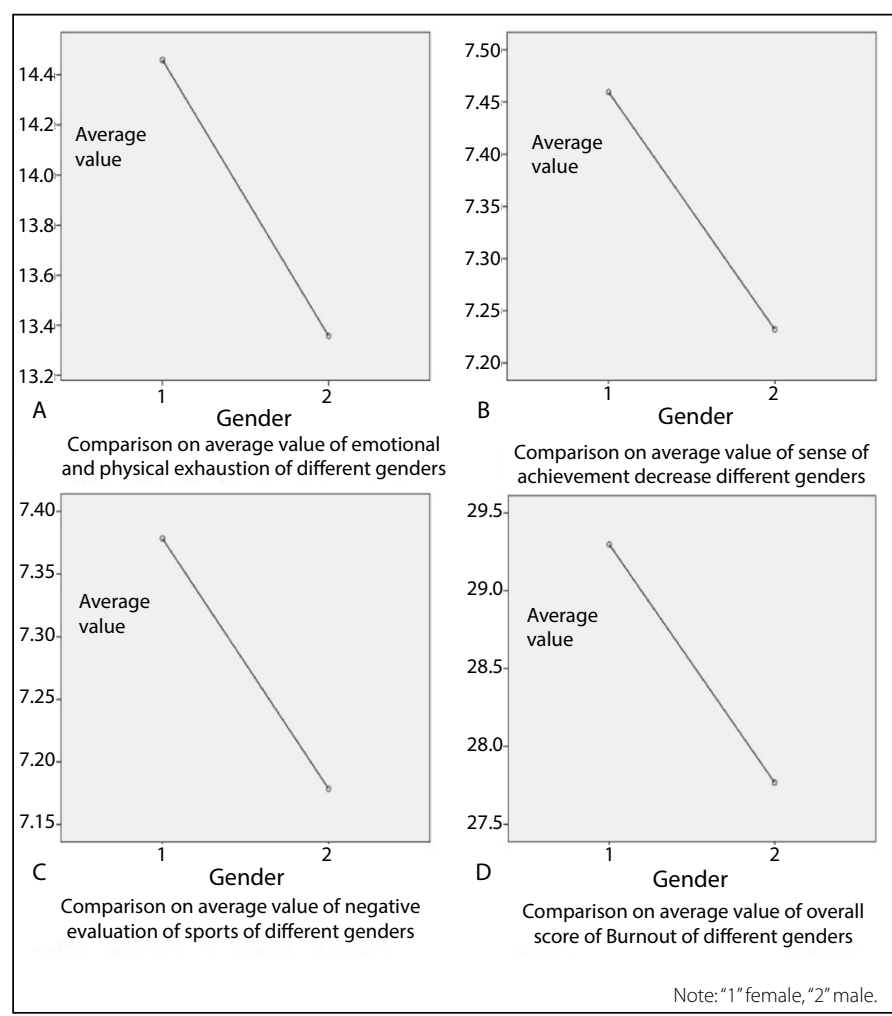

Figure 1. Analysis on the comparison on the burnout level of juvenile trampolinists of different genders. 


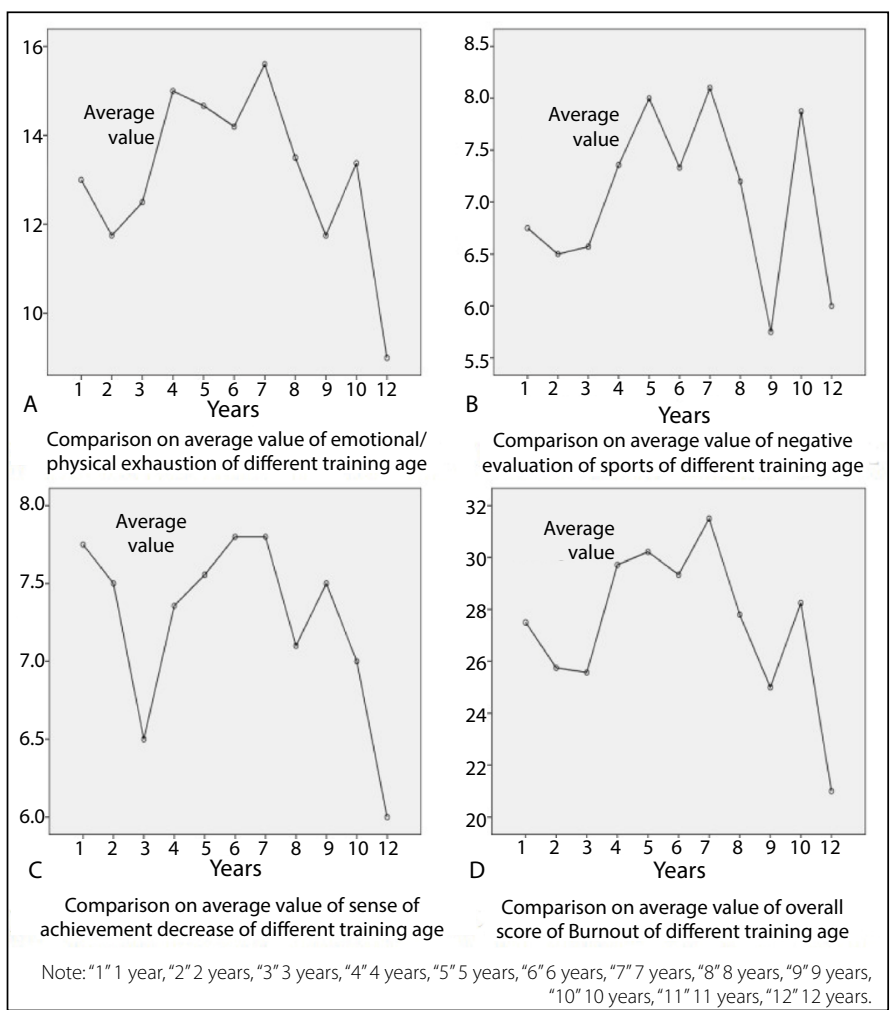

Figure 2. Analysis on the comparison on the burnout level of juvenile trampolinists of different training age.

amount and intensity. The training load has both positive and negative effects and positive adaptation to the training load will help the athletes to recover in excess and improve their performance in the competition; otherwise, it will lead to burnout. ${ }^{10,11}$

Athletes whose training age has reached 5 years are in the intermediate training stage, and they have certain cognition of trampoline techniques and training rules, and their self-esteem and self-confidence are relatively stronger. In view of this, trampolinists in the primary, intermediate or advanced training stage will develop burnout.

Significance value between overall score of juvenile trampolinists and their education stage is 0.563 , that is, Sig. $=0.563>0.05$, negative evaluation of sports > emotional/physical exhaustion > sense of achievement decrease.

Figure 3 indicates that, in terms of burnout level of juvenile trampolinists of different education stages, senior high school>primary school>junior high school. Athletes of senior high school are faced with more pressure, and factors such as competitions, training and college entrance examination will produce a continuous negative evaluation of athletes, and make them prone to burnout symptoms when being under great pressure continuously. As athletes of senior high school are faced with plenty of competitions, coaches will conduct intensive training before the competition, and the daily training amount and intensity will increase gradually, easily causing emotional/physical exhaustion.

Significance value between overall score of juvenile trampolinists and their athlete level is 0.650 , that is, Sig. $=0.650>0.05$. Sig values are respectively 0.573(sense of achievement decrease), emotional/physical exhaustion > sense of achievement decrease $>$ negative evaluation of sports.

Figure 4 indicates that, in the comparison of overall score on burnout of different athlete levels, training team member $>$ first grade $>$ second grade>master; comparison of emotional/physical exhaustion of different athlete levels, Athletes of first grade are in the transition from intermediate training stage to advanced training stage and it is urgent for them to achieve excellent results in order to enter higher training teams, and the training amount and intensity increase gradually, so the average value of emotional/ physical exhaustion of athletes of first grade will be relatively higher.
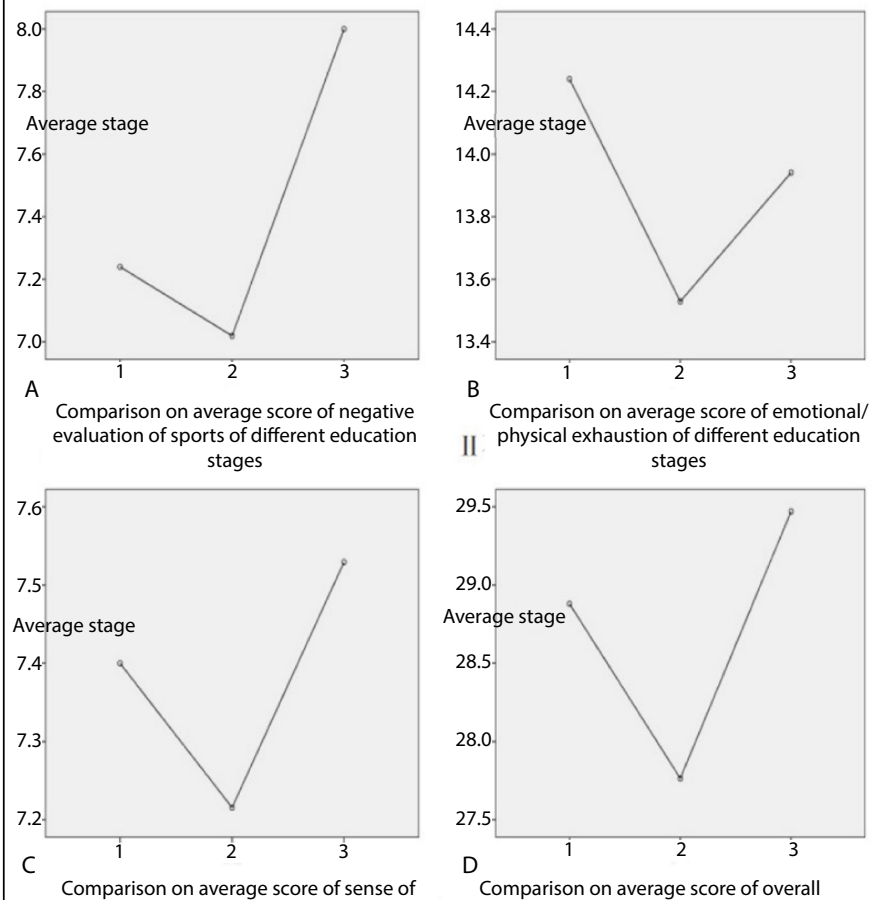
Chievement decrease of different education stages

Note:" "1"Primary School, "2" Junior High School, "3"Senior High School.

Figure 3. Research on the relation between juvenile trampolinists of different education stages and their burnout level.

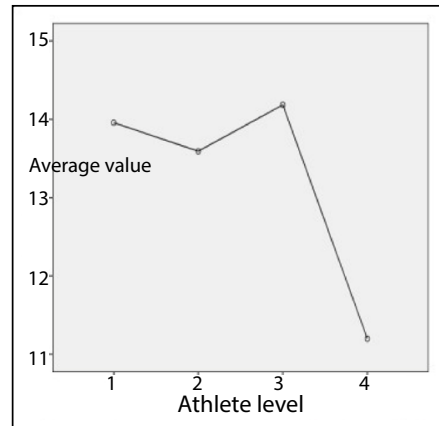

Comparison on average value of emotional/ physical exhaustion of different athlete levels

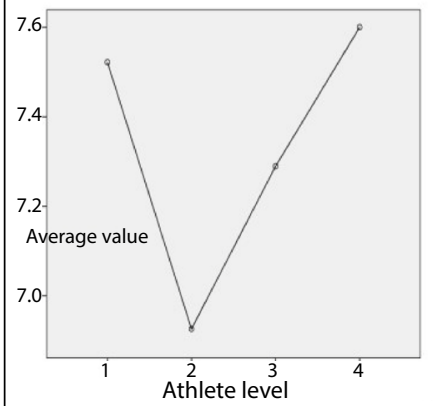

Comparison on average value of negative evaluation of sports of different athlete levels

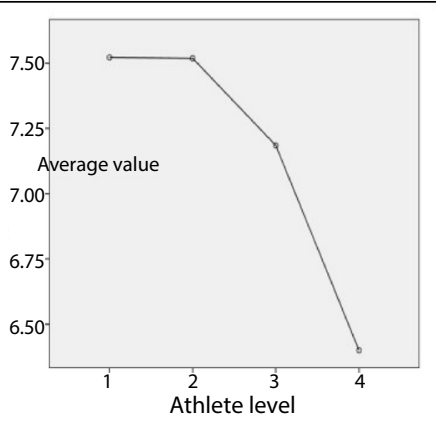

Comparison on average value of sense of achievement decrease of different athlete levels

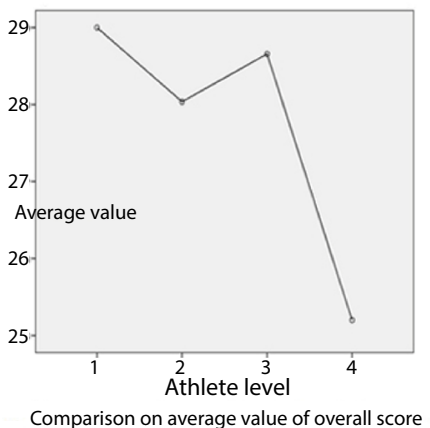

Comparison on average value of overall score of Burnout of different athlete levels
Note:"1"Training Team Members, "2" Athletes of Second Grade, "3" Athletes of First Grade, "4"Athletes of Master Level

Figure 4. Analysis on the comparison on the burnout level of juvenile trampolinists of different athlete level.

\section{Analysis on relevant affecting factors of burnout level of juvenile trampolinists}

On the burnout of juvenile trampolinists, there are great significant correlation $(P<0.01)$ between overload factor.

In terms of emotional/physical exhaustion, $R$ value is $0.862^{a}, R^{2}$ value is 0.743 , the regression equation can explain $74.3 \%$ of the overall variation. The standard regression equation means: emotional/physical 
exhaustion $=0.297^{*}$ overload factor $+0.338^{*}$ personal factor $+0.274^{*}$ situational factor -1.870 . The above analysis indicates that the overload factor, personal factors and situational factor have very important influence on athletes' emotion/physical exhaustion.

On the burnout of juvenile trampolinists, there are great significant correlation $(P<0.01)$ between overload factor.

In terms of sense of achievement decrease, $R$ value is $0.670^{2}$, $R^{2}$ value is 0.448 , the regression equation can explain $44.8 \%$ of the overall variation. The standard regression equation means: emotional/physical exhaustion $=0.142 *$ overload factor $+0.121 *$ personal factor $+0.133^{*}$ situational factor+0.504.

In terms of the personal factor, it needs improving athletes' quality and helping pursuing goals of great difficulty as well as improving their cognitive level, and regulates their behaviors by avoiding negative social evaluation.

On the burnout of juvenile trampolinists, there are great significant correlation $(\mathrm{P}<0.01)$ between overload factor.

In terms of sense of achievement decrease, $R$ value is $0.735, R^{2}$ value is 0.540 , the regression equation can explain $54.0 \%$ of the overall variation. Sense of achievement decrease $=0.108^{*}$ overload factor $+0.074^{*}$ personal factor $+0.179^{*}$ situational factor +0.680 , which indicates that the overload factor and situational factor have very important influence on athletes' negative evaluation of sports.

\section{CONCLUSIONS}

The burnout level of juvenile trampolinists aged U10-16 in China is below the moderate level, and the overall burnout level of athletes is not high.
Through the variance analysis, it is concluded that the overall level of burnout of athletes is not significantly affected by different genders, training age, education stage and athlete level $(P<0.05)$.

In terms of burnout of juvenile trampolinists, there is a very significant positive correlation $(P<0.01)$ between overload factor, personal factor, and situational factor, and emotional/physical exhaustion, sense of achievement decrease, negative evaluation of sports.

\section{SUGGESTIONS}

1. More attention should be paid to the burnout of female juvenile trampolinists players; intervention and regulation of burnout of athletes with training age of 7 years should be increased; the prevention of burnout of senior high school athletes should be increased; more attention should be paid to burnout phenomenon of training team members.

2. Coaches and relevant managers should control burnout frequency of strengthen communication in daily life and training, and add courses of self-regulation methods on burnout into daily learning.

3. Athletes should be guided from a subjective perspective to follow the basic psychological needs theory and self-determination theory, and should actively learn the methods to alleviate burnout, while avoiding the choices of extremely difficult stunts.

4. Social support for trampoline should be strengthened so that athletes can obtain wider support for the purpose of putting all their minds into training and competition.

All authors declare no potential conflict of interest related to this article

AUTHORS' CONTRIBUTIONS: Each author has made an important personal contribution to this manuscript. Benyu Feng analyzed and explained the burnout level and related data of adolescent trampoline athletes in high temperature environment, which is an important contributor to the writing of manuscripts. Yu Yuan explained the influencing factors of burnout level and was the main contributor to writing the manuscript. all authors are reading and approving the final manuscript.

\section{REFERENCES}

1. Raedeke TD. Is athlete burnout more than stress? A commitment perspective. J Sport Exercise Psy 1997;19(4):396-417.

2. Zhang L, Mao Z. Athletic psychology. Higher Education Press. 2007;1:1.

3. Xing S, Yu G, Wang L. A review of the research on athlete burnout. Journal of Beijing Sport University. 2007;4:486-8

4. Taris TW, Stoffelsen J, Bakker AB, Schaufeli WB, Van Dierendonck D. Job control and burnout levels across occupations. Psychological Reports. 2005 [cited 2021 Jun 9];97:955-61. Available from: https:// www.wilmarschaufeli.nl/publications/Schaufeli/245a.pdf

5. Lemyre PN, Hall HK, Roberts GC. A social cognitive approach to burnout in elite athletes. Scand J Med Sci Sports. 2008;18(2):221-34.

6. Xie B, Yao JX. Sociological analysis of psychological fatigue and psychological exhaustion of professional athletes. Journal of Tianjin University of Sport. 2010;25(3):234-7.
7. Zhang LC, LiSH, LiuY. A review of the theoretical research progress of exercise-induced psychological fatigue. Journal of Physical Education. 2014;21(1):98-103.

8. Feng T. Research on the causes and recovery of burnout of Chinese elite swimmers. Central China Normal University, 2015.

9. Silva JM. An analysis of the training stress syndrome in competitive athletic. J Appl Sport Psychol. 1990 [cited 2021 Jun 6];2:5-20. Available from: https://www. semanticscholar.org/paper/An-analysis-of-the-training-stress-syndrome-in-Silva/ b063be80db060e8b90c8d195ace6735f56a965da

10. Cai L, Ji L. A review of research on fatigue and psychological exhaustion during exercise. Journal of Physical Education. 2005;3:54-6.

11. Gustafasson H, Kentt G, Hassmén P. Athlete burnout: An integrated model and future research directions. IntRev Sport Exerc Psychol. 2011 [cited 2021 Jun 6];4(1):3-24. Available from: https://researchprofiles.canberra.edu.au/en/publications/athlete-burnout-an-integrated-model-and-future-research-direction 